\title{
Counselove: Marital Counseling Android-Based Application to Promote Marital Satisfaction
}

\author{
Widodo Budiharto ${ }^{1}$, Meliana ${ }^{2}$, Pingkan C.B. Rumondor ${ }^{3}$ \\ ${ }^{1,2}$ School of Computer Science, Bina Nusantara University, Jakarta-Indonesia \\ ${ }^{3}$ Psychology Department, Bina Nusantara University, Jakarta-Indonesia
}

\begin{tabular}{l} 
Article Info \\
\hline Article history: \\
Received Sep 9, 2016 \\
Revised Nov 15, 2016 \\
Accepted Nov 30, 2016 \\
\hline
\end{tabular}

Keyword:

Android

Fuzzy logic

Marriage satisfaction

Web monitoring

\begin{abstract}
This paper presents the development of Android-based framework for improving marital satisfaction. Classic research in psychology found that stability of marriage is based on the ability to create and maintain a positive interaction ratio five times more than negative interactions. Based on that, we present Counselove, a mobile application intended to record information of daily positive behaviors (joking, showing affection) of couples who use the application. We propose a method where the apps can determine users' marital satisfaction level and also can help users increasing their marital satisfaction based on the relationship satisfaction questionnaire and the assessment of user's self reported behaviors to their partners using fuzzy logic. The experimental results shown the application is running well on mobile devices based on Android platform. Lastly, we provide result of in depth interview with two users. Further research and development of the Counselove apps are discussed.
\end{abstract}

Copyright () 2017 Institute of Advanced Engineering and Science. All rights reserved.

\section{Corresponding Author:}

Widodo Budiharto,

School of Computer Science,

Bina Nusantara University,

Palmerah, Jakarta-Indonesia.

Email: wbudiharto@binus.edu

\section{INTRODUCTION}

Divorce rate through out the world is increasing. In Europe, the divorce rate from 1965 is 0.8 from 1000 person and increased to 2 from 1000 person in 2012. While in America, it increases from 2.7 in 2009 to 2.8 in 2012. Similar trend occur in Asia, from 2.5 in 2009 to 2.7 in 2011 . Especially in Indonesia, the divorce rate increase $23.9 \%$ percent, from 223,371 cases in 2009 to 276,791 cases in 2011 [1]. This number showed that keeping marriage is getting more difficult from time to time.

Vulnerability-Stress-Adaptation model of marriage posit that marriage stability is affected by couple's external stress, adaptation process, and marital satisfaction [2]. In order to keep marriage stability, couple should activate skills needed for adaptation to increase marital satisfaction and prevent more serious problem such as divorce. Marital satisfaction can be defined as a result of greater perceived benefits of marriage [3]. From multi-dimensional perspective, marital satisfaction include general evaluation of marriage from extremely satisfied to dissatisfied and also evaluation of more specific areas in marriage such as personality issues, communication, conflict resolution, financial management, leisure activities, sexual relationship, children and parenting, family and friends, equalitarian roles, and religious orientation [4].

There are several evidence based marriage enrichment program to help couple increase marital satisfaction, such as PREPARE-ENRICH [5], PAIRS [6], Hope focused Marital Enrichment [7], PREP, Relationship Enhancement, Couple Communication Program [8]. All the program require couple to meet counselor. Having to enroll to those programs require efforts in terms of time and money. On the other hand, according to ILO's report, there are increasing number of woman who work freelance and decreasing of 
unemployed women in 2013, compare to 2009 in Indonesia [9] resulting in more dual career marriage. This implied they have little time to spend together, let alone going to marriage enrichment program. On the other hand, 40\% young people age 25-34 years old, including husband and wife use android smartphone [10]. Therefore, there are opportunities to use smartphone apps to help build marital satisfaction.

Mobile application has been used to promote behavioral healthcare [11], integrated with clinical practice [12] and also promote wellbeing [13]. According to ABI research, 9 billion apps were downloaded worldwide to mobile phone in 2010. In 2011, there were roughly 17,000 health-related applications for iPhones, Android based devices, and other mobile phones and tablets. [12] According to Statista.com, as of May 2014, there are 33,900 apps worldwide dedicated to health and fitness for the Android operating system. [14] This showed that the digital health industry has grown significantly. According to unified theory of acceptance and use of technology (UTAUT), one of the consumer technology use is to facilitated condition, refer to consumer's perceptions of the resources and support available to perform a behavior [15]. There are several mobile apps that provide information, activities and support to enhance romantic relationship [16]. These applications has features to promote communication [17], sharing moments, enhancing intimacy, even filling couple's "love tank" in a fun way [18]. Some of this application is developed by well experienced marital counselor such as John Gottman [18]. Table 1 describes several apps that aim to promote romantic relationship.

Table 1. Apps That Promote Romantic Relationship

\begin{tabular}{|c|c|c|c|}
\hline No & Apps & Description & Platform \\
\hline 1 & Avocado & Messaging, share photos, to do list, calendar. & Android \& IOS \\
\hline 2 & Couple & $\begin{array}{l}\text { Messaging, share photos, calendar, sketches, } \\
\text { thumbkisses, share location. }\end{array}$ & Android \& IOS \\
\hline 3 & Pillowtalk & Email creative playtime ideas for couples & Android \& IOS \\
\hline 4 & $\begin{array}{l}\text { Loving - Couple } \\
\text { Essential }\end{array}$ & $\begin{array}{l}\text { Messaging (text, voice), share photos, menstrual } \\
\text { calendar. }\end{array}$ & Android \& IOS \\
\hline 5 & Kindu & Match sexual related activity. & Android \& IOS \\
\hline 6 & Twyxt & Messenger, share photos, calendar. & Android \& IOS \\
\hline 7 & Between & Messaging (text, voice), share photos, calendar. & Android \& IOS \\
\hline 8 & Love Maps & Questions idea for conversation. & Android \& IOS \\
\hline 9 & Kahnoodle & Game play, rewards for loving interactions. & Android \& IOS \\
\hline 10 & Couplete & $\begin{array}{l}\text { Messaging, share photos, love letters, relationship } \\
\text { story, calendar, to do list, activity ideas. }\end{array}$ & Android \\
\hline 11 & Kouply & Game play, rewards for loving interactions. & IOS \\
\hline 12 & Goodforapp & Craft personalized coupons. & IOS \\
\hline
\end{tabular}

Those applications emphasizing private communication, and content sharing. None of them include psychological assessment of marital satisfaction. Also, none of them specifically use research finding form Gottman and Levenson [20]. Classic research from Gottman and Levenson [20] found that stability of the marriage is based on the ability to create and maintain a positive interaction ratio 5 times more than negative interactions. Furthermore, Gottman and Driver [21] found that the couple could feel the satisfaction of their marriage in simple way, which is through some moments/things that generally considered as unimportant, such as joking and showing affection. These simple moments are very important for the healthy and stability of marital relationship. It can strengthen the intimacy of couple and become a strong foundation in marriage. By having a strong foundation, then the couple can be more prudent in dealing with problems.Based on that, we interested to develop the system to increase marriage satisfactions based on positive interactions from couples.

\section{RESEARCH METHOD}

\subsection{Architecture of System}

Android is an open source and Linux-based Operating System for mobile devices such as smart phones and tablet computers. Android was developed by the Open Handset Alliance, led by Google, and other companies. Android offers a unified approach to application development for mobile devices which means developers need only develop for Android, and their applications should be able to run on different devices powered by Android. Android operating system is a stack of software components which is roughly divided into five sections and four main layers as shown below in the architecture diagram [22]. Figure 1 ahows android architecture diagram. 


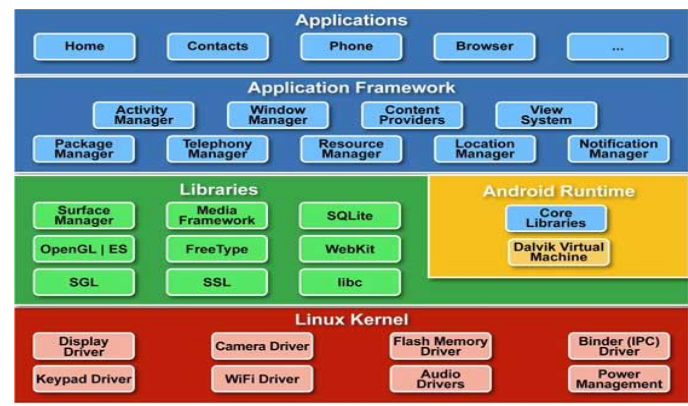

Figure 1. Android architecture diagram

At the bottom of the layers is Linux - Linux 2.6 with approximately 115 patches. This provides basic system functionality like process management, memory management, device management like camera, keypad, display etc. This system provides a survey for user to obtain their level of marriage satisfaction. Then the system explains the user about their marriage condition, also provides some advices and motivations to the user. If user agree to continue using this system, then the system gives them some tasks, articles in order to increasing their marriage satisfaction. In addition, the system ask user to fill their interaction with their partner everyday in order to recognize how well their marriage interaction. In few days, the system will provide a survey again to compare their first score and their new score in order to recognize that their level of marriage satisfaction is increasing, decreasing, or not changing. Data of user in securely save to web service using PHP and MySql. We develop an interactive application based on Java Platform [23-24]. Figure 2 below is a communication model based on web services that shows architecture of our application for marriage satisfaction.We design a user interface where user can make activities in this system such as Take the Survey, Fill Activity, Add New Activity., Complete the Task, Read the Article and Turn on/off the Sound.

We design a use case diagram based on Whitten [25]. Figure below is a use case diagram from ourapplication called Counselove that consists of Take the survey, Fill Activity, Add New Activity, Complete the Task, Read the Article and Turn on /off the Sound as shown in Figure 2:

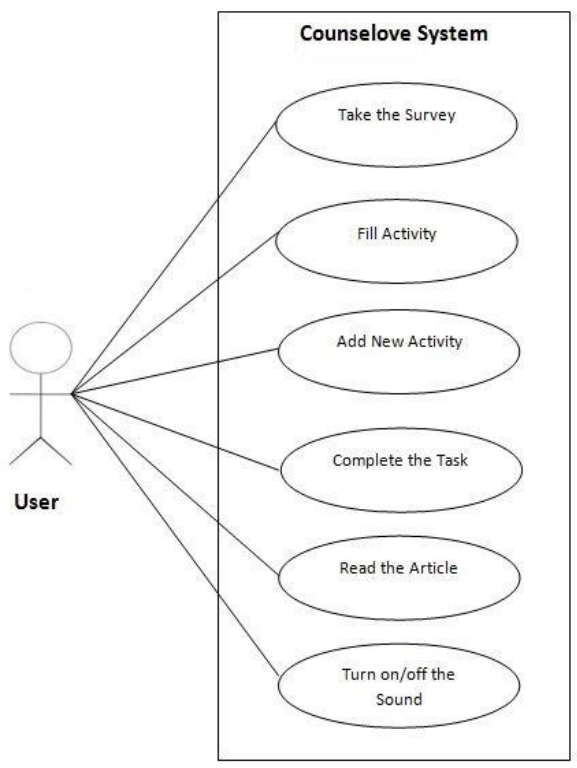

Figure 2. Usecase diagram of the Counselove systems

\subsection{Design of Fuzzy Logic for the System}

The fuzzy logic algorithm is an artificial intelligence algorithm that uses mathematical logic to solve to by the data value inputs which are not precise in order to reach an accurate conclusion, and has been used 
widely for decision making such as [31]. A fuzzy logic approach is used to construct the marriage satisfaction model. As describe in our previous paper [30]. we can measure how satisfied a couple in communication, balance of roles, agreement, openness, intimacy, social intimacy in relationships, sexuality, financial, spirituals shown in Figure 3 to 9, to make a measurement the quality of their marriage satisfaction:

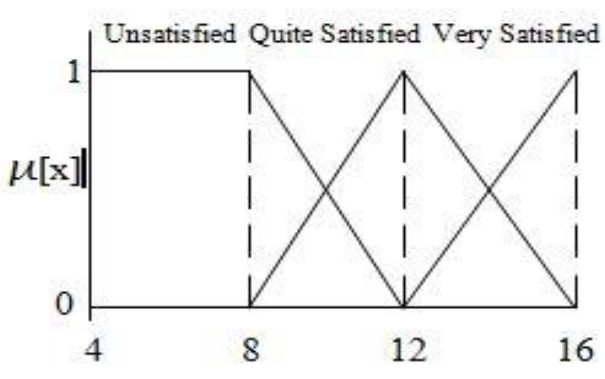

Figure 3. Fuzzy Logic of Communication

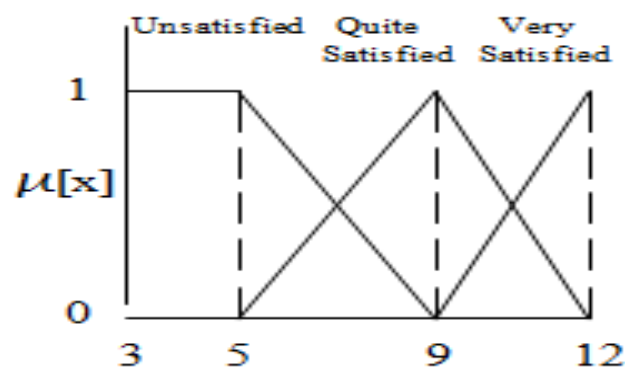

Figure 5. Fuzzy logic of Openness

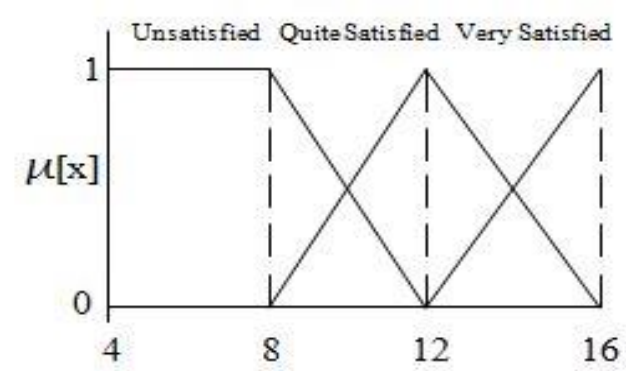

Figure 7. Fuzzy logic of Social Intimacy in Relationships

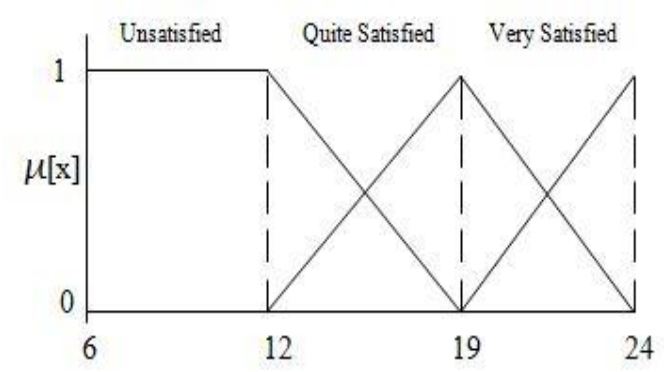

Figure 4. Fuzzy logic of Balance of Roles

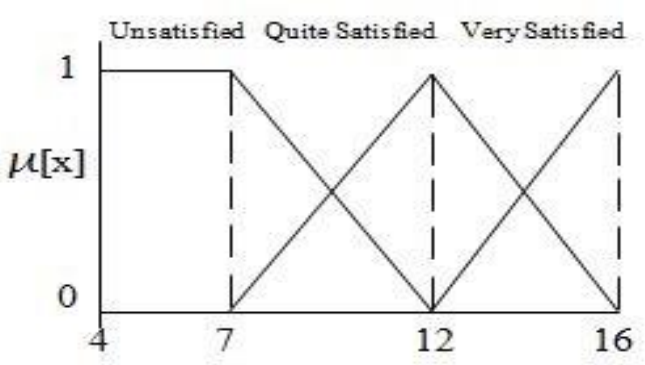

Figure 6. Fuzzy logic of Intimacy

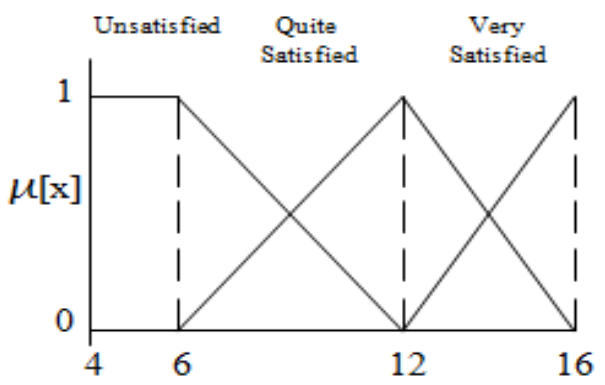

Figure 8 . Fuzzy logic of Sexuality

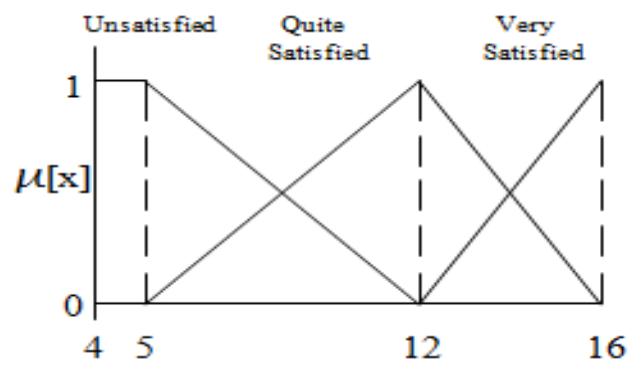

Figure 9. Fuzzy logic of Financial 
Based on the fuzzy logic, we create 10 rules to determine how satisfied a couple with their marriage. These are some examples of the rules:

If communication "very satisfied" and balance of roles "verysatisfied"andagreement "very satisfied" and openness "very satisfied" and intimacy "very satisfied" and social intimacy in relationships "very satisfied" and sexuality "verysatisfied"andfinancial "very satisfied" and spiritual "very satisfied" then marriage satisfaction is "very satisfied"

If communication "quite satisfied" and balance of roles "quitesatisfied" andagreement "quite satisfied" and openness "quite satisfied" and intimacy "quite satisfied" and social intimacy in relationships "quite satisfied" and sexuality "quite satisfied" andfinancial "quite satisfied "and spiritual "quite satisfied" then marriage satisfaction is "quite satisfied"

If communication "unsatisfied" and balance of roles "unsatisfied" and agreement "unsatisfied" and openness "unsatisfied" and intimacy "unsatisfied" and social intimacy in relationships "unsatisfied" and sexuality "unsatisfied" and financial "unsatisfied" and spiritual "unsatisfied" then marriage satisfaction is "unsatisfied".

\subsection{Getting the Level of Marriage Satisfaction}

Based on Karney [2], marital satisfaction is an evaluation of the relationship depends on the good or bad of adaptive processes in the couple, which is influenced by the enduring vulnerabilities and stressful events as shown in Figure 10:

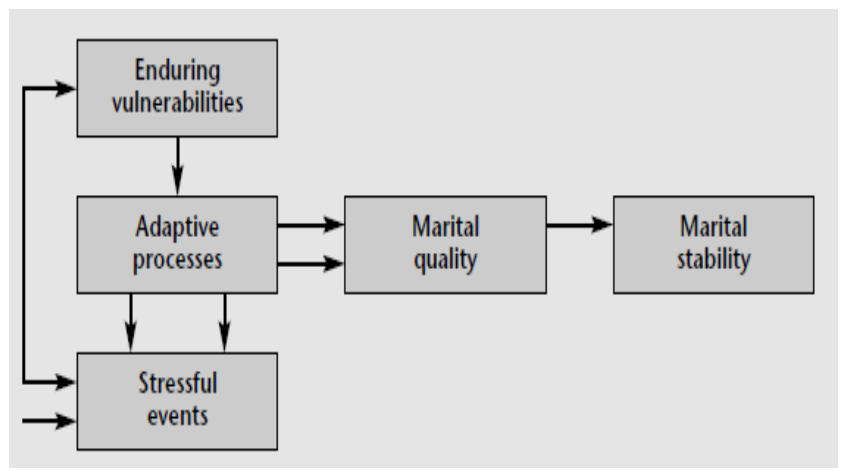

Figure 10. Vulnerability-Stress-Adaptation Model of Marriage [2]

Based on concept in figure 10, our system provides user a survey in order to get their level of marriage satisfaction. This survey is constructed for couples in Indonesia, especially urban area such as Jakarta. It is constructed based on the dimensions of the three marital satisfaction measurement, namely Dyadic Adjustment Scale [26], ENRICH marital satisfaction [4], and Marriage Satisfaction Questionnaire [27]. Researchers make some adjustments to the conditions of young adults aged couples that live in urban areas by interviewing four couples working in Jakarta. Interviews showed there were 9 dimensions in urban couples marital satisfaction. The questionnaire consists of 38 questions, which are divided to 9 dimensions [28].

a. Communication (4 items)

b. Balance of Roles (6 items)

c. Agreement (4 items)

d. Openness (3 items)

e. Intimacy (4 items)

f. Social Intimacy in Relationships (4 items)

g. Sexuality (4 items)

h. Financial (4 items) and

i. Spiritual (5 items)

These dimensions are used to get where are the weaknesses and the strengths in the user's relationship with theirpartner. By knowing it, the system can give the appropriate advices and motivations to user.There are 4 options to answer each question, which are "very satisfied" is 4 and "satisfied", its value 
is 3; "dissatisfied" is 2 and "very dissatisfied", its value is 1 . Associated with given multiple choice answers for each question, so it can be summed the max and min score for each dimension:

Table 2. Dimensions of marriage satisfaction

\begin{tabular}{cccc}
\hline Dimension & $\begin{array}{c}\text { The Number of } \\
\text { Questions }\end{array}$ & Min Score & $\begin{array}{c}\text { Max } \\
\text { Score }\end{array}$ \\
\hline Communication & 4 & 4 & 16 \\
Balance of Roles & 6 & 6 & 24 \\
Agreement & 4 & 4 & 16 \\
Openness & 3 & 3 & 12 \\
Intimacy & 4 & 4 & 16 \\
Social Intimacy in Relationships & 4 & 4 & 16 \\
Sexuality & 4 & 4 & 16 \\
Financial & 4 & 4 & 16 \\
Spiritual & 5 & 5 & 20 \\
\hline
\end{tabular}

Then each value is summed, so the system will knowing is the user satisfied with his/her marriage or dissatisfied by total value from the survey. From the value, system will know, in which area the couple is satisfied the most and which they are less satisfied.

\subsection{Increasing Marriage Satisfaction}

Gottman and Driver [21] found that couples can feel the satisfaction of the marriage relationship through the simple expedient of the case / small moments that are generally not considered important, such as a joke or show affection. Simple moments like this are very important to the health and stability of marital relations. These moments can strengthen the intimacy couples, and became a strong foundation in a marriage relationship. By having a strong foundation, it can be a better partner in the face of conflict.Therefore in this system is provided "Fill Activity" module, which is used to input user's activity (interaction) that they have done with their partner. Then the system recognizes whether the interaction is negative or positive. After that, the system calculates the ratio of the activities that user have filled. Is the ratio is $5: 1$ (positive : negative), or lower, or higher. If the ratio is lower than $5: 1$, then the system will give a warning to user, and give some tasks in order to increasing the ratio. The ratio $5: \mathbf{1}$ is equal to5/6 $* \mathbf{1 0 0 \%}=\mathbf{8 3 . 3 \%}$, so the IF-THEN RULES are:

IF \{("positive activity" divided "total activity" times "100”) is less than "83.3"\} THEN give the warning

Aside from the warning, the apps also provide task that can increase positive behavior. Those tasks are simple task such as: smiling to your partner, tell a neutral joke to your partner, tell a happy experience to your partner, respond to your partner's story, say "thank you" and other simple daily activities.

\section{RESULTS AND ANALYSIS}

Experiments of this system have been tested for getting level of marriage satisfaction of a person. Based on the experiment, the system runs very well with the capability to calculate the total value in the survey as shown in Figure 11. This application can be download at Google Play [29]. We also have questioners to testing this application to young couples in Jakarta with about 100 respondents between 20-40 years old. 


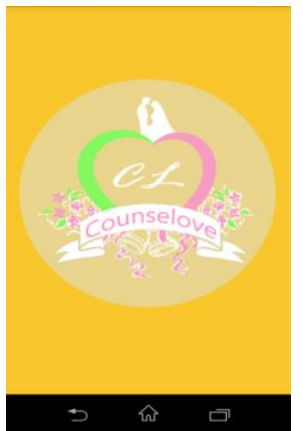

(a)

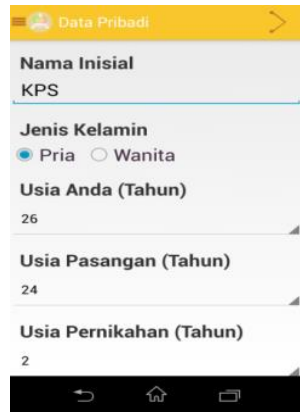

(c)

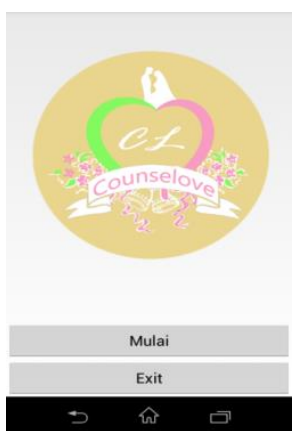

(b)

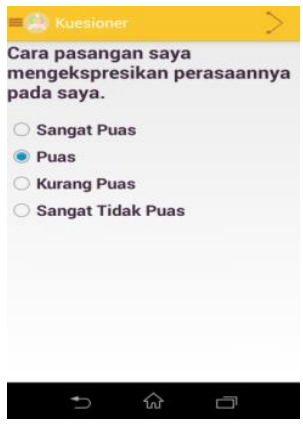

(d)

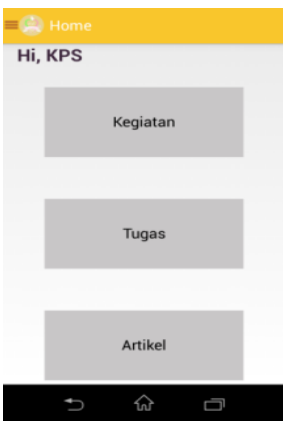

(e)

Figure 11. Result of simulation using Sony Xperia L (4.2.2 Jellybean), Splashscreen (a), welcome page for starting or exit from application (b), Personal Data form for the questionnaire (survey) (c), page of the questionnaire (d) main page for choosing fill activity, complete task, and read article (e) [29]

In the first stage, user registered by filling out one form consisting of name, gender, user age, the age of the couple, marriage age, the age of children (if any), the last user education, occupation, and address. Then on the next stage, contained user's agreement and Terms and Conditions of the applications. The administration web (www.counselove-pernikahan.com) shown in Figure 12 and 13.

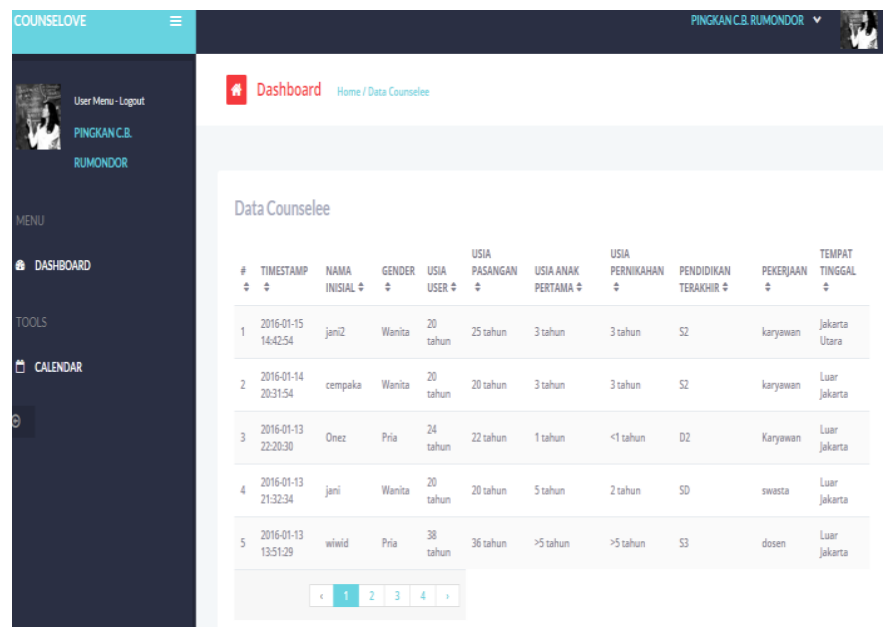

Figure. 12. Information of user and their activities 


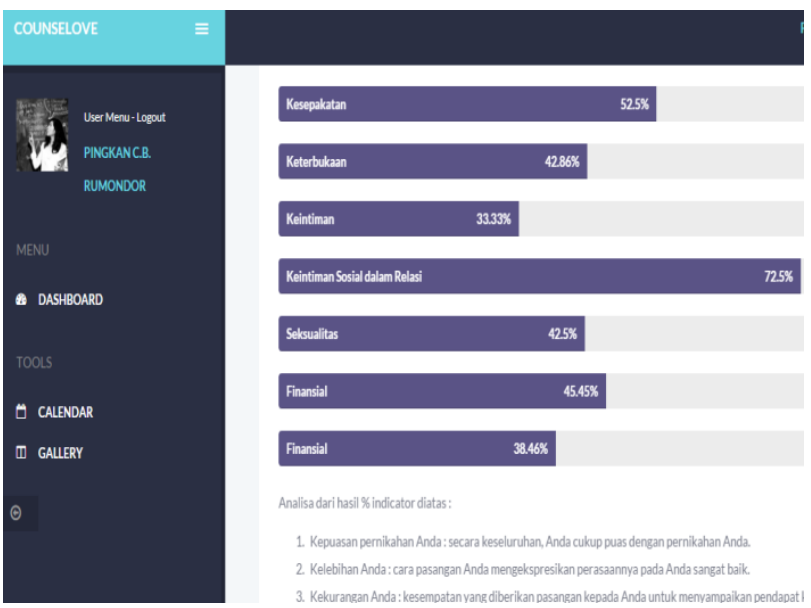

Figure. 13. The questioner result from interface back-end

Through the interface back-end system, the results of the questionnaire will be validated and be represented in a diagram. User will be given the results of the analysis level of marital satisfaction results, as well as the advantages and lack of activities and tasks that can be performed by the user on a daily basis. After testing phase, we invite two female respondents, age 22 and 24 who are marriage for 1-2 years with one children age 1 and 2 years old to try Counselove. After that, we ask them about their experience in using Counselove and whether they will use it daily. We also ask what positive and negative features from Counselove are. Lastly, we asked for suggestions to make the apps more functional.Both interview respondents think that the activity suggestions are useful as reference of daily activity with their spouse. Therefore, they will use it daily and will recommend it to their husband. The downside of this apps is the self-report mode, one of the respondent think that user can fake the daily activity in order to gain more score. Respondents also thinks that they may have no time to input the daily activity because now they are busy nurturing their toddler and doing household chores. One of the respondent suggest to add features regarding child rearing and family activities that includes husband, wife, and their child.

\section{CONCLUSION}

We successfully develop Android-Based application for increasing marriage satisfaction in Bahasa Indonesia for young married couple. This application can help users to determine the level of household harmony in their way that is easy, interactive, and interesting. This application can provide motivation and advice to the user in the life of the household. Based on the questioners, this application is really useful and interesting. Although, based on description of other apps for couple, there are some features that can be add to this apps. Those features are private messaging, shared content (photos, to do list, calendar), and content related child rearing. Further research can explore the efficacy of this apps in terms of promoting marital satisfaction in dual career couple who live in urban area, such as Jakarta, Indonesia by conducting randomized control trial experiment.

\section{ACKNOWLEDGEMENTS}

The authors wish to thank to Indonesian Directorate General of Higher Education (DIKTI) for Hibah Kompetensi Nasional 2015-2016 for this research.

\section{REFERENCES}

[1] UN Department of Economic and Social Affairs. United Nations Demographic Yearbook 2013. 2014. From http://unstats.un.org/unsd/Demographic/products/dyb/dybsets/2013.pdf

[2] Karney, B.R. "Keeping Marriage Healthy and Why it's So Difficult", From http://www.apa.org/science/about/psa/2010/02/sci-brief.aspx

[3] Stone, E., \& Shackelford, T. (2007). Marital satisfaction. In R. Baumeister, \& K. Vohs (Eds.), Encyclopedia of social psychology. (pp. 541-545). Thousand Oaks, CA: SAGE Publications, Inc. doi: $10.4135 / 9781412956253 . n 323$ 
[4] B.J. Fowers and D.H Olson, ENRICH Marital Satisfaction Scale: A Brief Research and Clinical Tool. Journal of Family Psychology, Vol. 7, No. 2, 1993, p. 176-185. DOI: 10.1037/0893-3200.7.2.176

[5] Mahin Askari, Sidek B. Mohd Noah, Siti Aishah Bt Hassan, Maznah Bt Baba. "Comparison the Effects of Communication and Conflict Resolution Skills Training on Marital Satisfaction". International Journal of Psychological Studies, Vol 4, No 1, 2012. DOI: 10.5539/ijps.v4n1p182.

[6] De Maria, R.M. "Distressed couples and marriage education". Family Relations, Vol. 54, p. 242-253. DOI: 10.1111/j.0197-6664.2005.00019.x

[7] Ripley, Jennifer S., Worthington, E.L. "Hope-focused and forgiveness-based group interventions to promote marital enrichment". Journal of Counseling \& Development, Vol. 80, No. 4, p. 452-63. DOI: 10.1002/j.15566678.2002.tb00212.x

[8] Scot F. Jakubowski, Eric P. Milne, Heidi Brunner, Richard B. Miller. "A Review of Empirically Supported Marital Enrichment Programs”. Family Relations, Vol. 53, No. 5, p. 528-536. DOI: 10.1111/j.0197-6664.2004.00062.x

[9] ILO. "Labour and social trends in Indonesia 2013: Reinforcing the role of decent work in equitable growth". Jakarta. 2013

[10] Musofa, D.Z. "Di Indonesia, Gadget Android didominasi Laki-laki." 2013. From http://m.merdeka.com/teknologi/di-indonesia-gadget-android-didominasi-laki-laki.html

[11] D.D. Luxton, A.M. Russell., N.E. Bush, M.C. Mishkind., and G.M. Reger, "mHealth for Mental Health: Integrating Smartphone Technology in Behavioral Healthcare", Professional Psychology: Research and Practice, Vol. 42, No. 6, 505-512, 2011. DOI: 10.1037/a0024485.

[12] M.E. Morris and A. Aguilera. "Mobile, Social, and Wearable Computing and the Evolution of Psychological Practice", Professional Psychology: Research and Practice, Vol. 43, No. 6, 622-626, 2012. DOI: 10.1037/a0029041.

[13] Lane, N.D., Mohammod, M., Lin, M., Yang, X., Lu, H., Ali, S. \& Campbell, A., "Bewell: A smartphone application to monitor, model and promote wellbeing", In 5th international ICST conference on pervasive computing technologies for healthcare (pp. 23-26).

[14] "Number of health-related apps worldwide as of May 2014, by category", Retrieved from: http://www.statista.com/statistics/449362/health-relevant-apps-worldwide-by-category/

[15] Venkatesh, Viswanath and Thong, James Y.L. and Xu, Xin, Consumer Acceptance and Use of Information Technology: Extending the Unified Theory of Acceptance and Use of Technology (February 9, 2012). MIS Quarterly, Vol. 36, No. 1, pp. 157-178, 2012. Retrieved from SSRN: http://ssrn.com/abstract=2002388

[16] Russo, F., "Want a Better Relationship? There's an App for That", 2013, Retrieved from: http://healthland.time.com/2013/02/13/want-a-better-relationship-theres-an-app-for-that/.

[17] About couple apps, Retrieved from: https://couple.me/about

[18] Talbert, M. W. "Tech Startup of the Week: Kahnoodle, An App to Keep Love Alive", 2013., Retrieved from: http://www.blackenterprise.com/technology/tech-startup-of-the-week-kahnoodle-an-app-to-keep-love-alive/

[19] “Gottman Apps", Retrieved from: http://www.gottman.com/iphone-apps-2/

[20] J.M Gottman and R.W. Levenson, "Marital Process Predictive of Later Dissolution Behavior, Physiology and Health", Journal of Personality and Social Psychology, Vol. 62, No. 2, p. 221-233, 1992. DOI: 10.1037/00223514.63.2.221

[21] J.L. Driver and J.M Gottman, "Daily Marital Interactions and Positive Affect during Marital Conflict Among Newlywed Couples", Family Process, Vol. 43, No. 3. p. 301-314, 2004. DOI: 10.1111/j.1545-5300.2004.00024.x

[22] S. Brahler, "Analysis of the Android Architecture", Karlsruhe: Karlsruhe Institute of Technology, 2010.

[23] J. Deitel, M. Harvey, “Java: How to Program. (9th edition)”, Prentice Hall, 2011.

[24] Fling, "Mobile Design and Development (1st edition)", O'Reilly Media, Inc., 2009.

[25] Whitten J.L., Bentley L.D., "Systems Analysis and Design Methods (7th edition)", New York: The McGraw-Hill Companies, Inc., 2007.

[26] Spanier, G.B. (1976). Measuring Dyadic Adjustment: New Scales for Assessing the Quality of Marriage and Similar Dyads. Journal of Marriage and the Family, Vol. 38, No. 1. (Feb., 1976), pp. 15-28.

[27] Sadarjoen, S.S., "Model Kualitas Perkawinan Berdasarkan Kepegasan Pasangan dan Gaya Penyelesaian Konflik Perkawinan: Studi Eksplanatif terhadap Pasangan Perkawinan Eksekutif Muda Pada Usia Perkawinan Sepuluh Tahun Pertama di Kota Bandung dan Jakarta”, Doctoral Disertation. Universitas Padjajaran, 2004.

[28] P.C.B. Rumondor and G.V. Paramita, "Marital Satisfaction and couple's income among young adults of urban area", Psychology Department research report, BINUS University-Jakarta, 2012.

[29] https://play.google.com/store/apps/details?id=com.jeffreyjohan14393.counselove

[30] Budiharto, W., Rumondor, P.C.B., Meiliana, M., \&Ferdianto, F. (2015). Android-based framework for increasing marriage satisfaction based on psychological aspects. Paper presented at the 2015 4th International Conference on Informatics, Electronics and Vision, ICIEV 2015, doi:10.1109/ICIEV.2015.7334024

[31] Iswanto, Oyas Wahyunggoro and Adha Imam Cahyadi, "Path Planning Based on Fuzzy Decision Trees and Potential Field", International Journal of Electrical and Computer Engineering (IJECE), Vol. 6, No. 1, February 2016, pp. 212 222.

[32] M. Kumar Bhuyan, Durga Prasad Mohapatra and Srinivas Sethi, "Software Reliability Prediction using Fuzzy MinMax Algorithm and Recurrent Neural Network Approach", International Journal of Electrical and Computer Engineering (IJECE), Vol. 6, No. 4, August 2016, pp. 1929 - 1938 